\title{
Implementation of chain story techniques to improve english speaking ability at imanuel YPK vocational high school, Sorong City
}

\author{
Lulu Jola Uktolseja, Sherly Gaspersz
}

Department of English Education, Victory University of Sorong, Indonesia

\begin{tabular}{l}
\hline \hline Article Info \\
\hline Article history: \\
Received Jun 15, 2019 \\
Revised Aug 5, 2019 \\
Accepted Sep 1, 2019
\end{tabular}

Keywords:

Chain story technique

English speaking ability

\begin{abstract}
The function of English as the international language that connects various countries with different languages makes English as an important communication tool to be learned and taught for students from various levels of education as the provision to face the current era of globalization. The chain story technique that implemented in this research, is a technique that is suitable to be used to teach students who have not dared to actively use English. This technique helps students of Imanuel YPK Vocational High School, Sorong City to work as a team and help each other to construct the sentence. This study was designed in the form of Classroom Action Research (CAR). The method of this research is a qualitative and quantitative method. The qualitative to explain the condition before and after the action. The quantitative to count the score of the students. As for the subject in this research is the Class X Automation and Office Management. This is done in order to obtain valid and reliable research data. Data collection techniques used were observation, test and interview. Results of the study showed that: (1) Based on the observation, the students are changed to be more brave and confident to speak English; (2) Based on the test, there is a very significant change towards the positive, when compared to the value of very good and good in cycle 1 which is $42 \%$ while in cycle 2 is $80 \%$, so there is an increase of $38 \%$; (3) Based on the interview, the students were happy and giving the good responses about the treatment and the progress they have done
\end{abstract}

Copyright (c) 2019 Institute of Advanced Engineering and Science. All rights reserved.

Corresponding Author:

Lulu Jola Uktolseja,

Department of English Education,

Victory University of Sorong,

Basuki Rahmat Street, KM 11.5, Sorong - West Papua, Indonesia.

Email: lulujola39@gmail.com

\section{INTRODUCTION}

In Indonesia English is a foreign language. It is defined as one language that is not the original language of most people in a particular country or region, which is not used as a means of communication in the government, work place, or even on the mass media. Foreign languages are very important to prepare the young generation to face the challenge of the future. This is because of the globalization era, which is very competitive [1]. Social life can be improved and a better job opportunity can be achieved if communication skills in English are enhanced [2]. Besides that, by having foreign language skills, especially English, especially English as the language of international communication, it will be easier to obtain clearer information [3]. The mastery of foreign languages including English does not inhibit or even strengthen the mastery of mother tongue, Indonesian [4]. English is one of the most common subjects that has been curriculated at elementary, junior high and high school levels as international subjects. In the performance the students are taught to understand the meaning of words, reading, and listening [5]. 
Nowadays, the learning process of English focuses on the speaking skill since a very young age. Speaking is the language skill which comes first in human's young age and is the most essential and most often used in communication [6]. Teaching English in Indonesia is more difficult, because English is not the first language in our country, but, a foreign language and dominantly as a third language in this country [7]. Students have become very difficult to develop the habit of communicating in English because both at home, in the community and in the school environment outside the English class, they do not find someone who is actively speaking English. Furthermore, some factors affecting English speaking skill are limited chance to speak English either in classroom or outside, minimum exposure to real English language situations that give them opportunities to practice English for communication and expression [8]. Moreover, the structure of English that is very different with Indonesian influencing the students understanding. EFL learners' speaking skill is affected by some linguistic components of language like phonology, syntax, vocabulary, and semantics and psychological factors such as motivation and personality [9].

The teacher's creativity in developing learning English in the classroom is the most important factor to increase the English learning quality. In the several decades, language teachers tend to use traditional teaching methods, such as introducing a new idea, giving rules deductively, or explaining the lesson directly [10]. It did not help the students to use target language directly. Nowadays learning develops and emphasizes speaking ability as the most important thing to prepare every individual to be able to communicate not only writing but verbally. Language learners sometimes evaluate their success in language learning based on how well they have improved in their spoken language ability [11].

Based on the curriculum of 2013, teaching English should be based on the context. Teaching should be contextual which was related to phenomenon and events in the real life [12]. We believe that language learning is a hard job. We cannot deny that many students may good at writing or reading but just some of them who may be good at speaking. They still use English passively to only communicate by text. Teachers as important milestones of learning success must be observant of the needs of students. The important elements for learning is the method that instructors use in their classes to facilitate language learning process [13]. This means that the type of input given determines the final outcome of the learning process.

The problem that is often faced by English language students is that they are forced to accept lessons in a way or technique that is not in accordance with their abilities. This causes the continuity between input, process, and output. Teachers should be more sensitive to being aware of the needs of the students they are teaching. The learning process in the classroom influences the success of education [14]. Nowadays, it has become obligatory for the teachers to rethink and renovate their teaching strategies with the changing times [15]. Teachers should be filled with energy, enthusiasm, and a learner-centered approach [16]. The accuracy of the selection of techniques is so important that the learning process can run optimally so as to achieve the learning objectives. The kind of methods or techniques used by teachers must give more opportunities toward students to practice the language [17]. Students who use effective strategies which make them comfortable in using English to communicate will be able to solve many problems in speaking English [18].

Teachers should encourage students' communicative competence all the time, and besides their limitations to use language fluently and accurately, they should provide them with spaces to interact with others or to immerse them in speaking activities that enhance their ability to use the target language [19]. Dealing with the purpose of teaching speaking purposes to use English actively, the chain story technique will fill the desire of it. The chain story technique is designed in a way that the students can be more active to create sentences and to help each other in a cooperative manner. When students are arranged in pair or group work, they have the opportunity to improve their speaking skills, students usually feel more confident, comfortable and free expressing their ideas without being afraid of making mistakes while in both pair or group work activities; correction usually takes place among students in the group [20].

Chain story technique helps students to learn in groups but not passively. Each student is invited to be involved in learning by connecting a story whose topic has been given first. Students will learn to string words slowly so that they will become accustomed to remember each sentence. The best way to learn is to experience the learning yourself. When students are invited to think together, search for words together and say the word, then the word or sentence directly will be stored into their respective memories. Imanuel YPK Vocational High School, Sorong City as one of the vocational schools in Sorong City under the Christian Education Foundation in Papua certainly continues work to improve students' abilities in English because Vocational Schools always want to produce graduates who are ready to enter the workforce. Based on the initial study, it is known that students in this school actually have the potential but do not have the courage to use English to speak. The purpose of this study is to apply chain story techniques to their effectiveness in improving their English speaking skills, as well as increasing students' self-confidence in speaking English.

Siska Apriyani [21] wrote a study entitled Improving Students' Speaking Ability Using Chain Story Technique In Text For Grade Recount VIII of SMP N 1 Wates In Academic Year 2016/2017. 
The research of this class action consists of two cycles. The results of this study indicate that the use of chain techniques is able to improve the speaking ability of students in recount texts successfully. Recount text is a text that tells about the experience. The application of chain story techniques makes students feel challenged in speaking [21].

Iponiasih [22] wrote a study entitled The Influence of Using Story Chain Activity on Procedural Text towards Students' Speaking Skill. The researcher employs quantitative research with the method of experiment. She uses a quasi-experimental design in the type of non-equivalent control group to get the sample. The data is collected using an oral test. Based on the research findings after calculating the data, the result shows that there is a significant influence of using chain story activity on procedural text towards students' speaking skill [22].

Lusi Fitriani \& Muslih Hambali [23] wrote a study entitled Teaching Speaking through Chain Storytelling to the Tenth Grade Students Of SMA Srijaya Negara Palembang. The sample of this study was 60 tenth grade students of SMA Srijaya Negara, which were divided into control and experimental group, and each group had 30 students. To collect the data, each group was assigned pretest and post test. The result from paired sample $t$ test showed that the mean difference in post test and pretest of experimental group was 16.000 at the significance level of $\mathrm{p}<0.05$ and since $t$ obtained was higher than t table $(9.649>2.04523), \mathrm{H}_{01}$ was rejected and there was a significant improvement in speaking skill of experimental group [23].

Chain story is an activity in which stories are written or made by multiple author; each author contributes a sentence to the story then forwards the entire text to a partner [24]. Furthermore, chain story activity is a kind of game which can be applied in language teaching and learning activity [25]. In English teaching and learning activity, this activity can be applied in helping students to master speaking skill through the group works. Speaking is one of the important skills in the process of language learning [26]. Through speaking, students will understand ideas, opinions, and information from others. The ability to speak English is the ability to express ideas and ideas in English.

\section{RESEARCH METHOD}

\subsection{Method}

To get a valid and reliable research result, researchers must use the right method to obtain data. The methodology has a very important role in every scientific research because it determines the quality of research results. The method of this research is a qualitative and quantitative method. The qualitative to explain the condition before and after the action. The quantitative to count the score of the students. This study was designed in the form of Classroom Action Research (CAR). Classroom action research was carried out through certain procedures had a cyclical model which consist of four activities. They are as follow (1) planning; (2) acting; (3) observing, and (4) reflecting. CAR is an investigation of scientific problem solving, which has been carried out by real teaching actions in the classroom. This class study is primarily concerned with teaching speaking through learning strategies using chain stories. In the CAR method, there are actions carried out in several cycles depending on needs. In the following Figure 1 is a CAR cycle model according to Kemmis and Taggart [27].

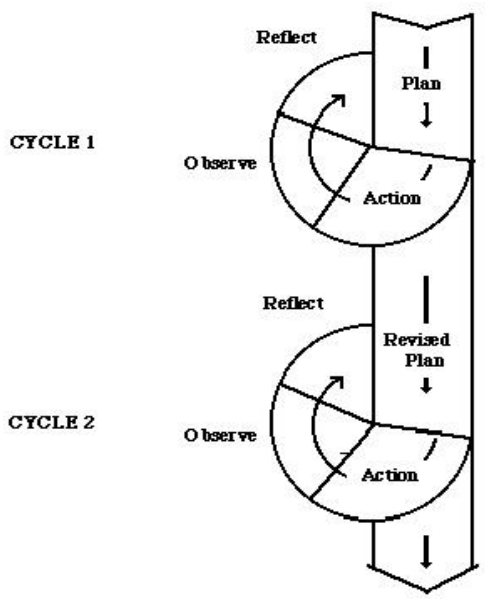

Figure 1. Classroom Action Research Cycle [27] 
In this cycle there are planning, taking action, observing and reflecting on the actions given in each cycle to decide the next action that must be taken so that this technique can be successfully adopted by students. This classroom action research is characterized by continuous change. The research will end if a predetermined indicator can be reached or has reached a level of saturation where the results only shift little or no change at all.

\subsection{Subject of research}

The limitation of the subject of research as objects, things or people place data for variables the research is inherent, and the one in question. In a study, the subject research has a very strategic role because, in the subject of research, that's the data about the variables studied observe. The subject in this research was the Class X Automation and Office Management.

\subsection{Data collection technique}

In this study, three types of data collection techniques were used. This is done in order to obtain valid and reliable research data. Data collection techniques used were observation, tests, and interview. Observations were made to see the learning process carried out by subject teachers. The aspects observed are the teaching and learning process before treatment and after treatment. The initial test was carried out to determine the ability of students to speak English. Interview given to students to capture information about students' perceptions regarding the implementation of activities that have been carried out. This is done so that the results of the processes that have been carried out become more convincing that they have been successfully implemented. Each value obtained is multiplied by 4, so that the maximum value is 100 .

Table 1. Value indicator for speaking assessment

\begin{tabular}{|c|c|c|c|}
\hline No & Speaking Components & Points & Indicator \\
\hline \multirow[t]{5}{*}{1.} & Pronunciation & 5 & a. Can pronounce correctly $\&$ articulate clearly \\
\hline & & 4 & b. Mostly correct pronunciation \& clear articulation \\
\hline & & 3 & c. Largely correct pronunciation \& clear articulation except occasional errors \\
\hline & & 2 & d. Frequently unintelligible articulations \\
\hline & & 1 & e. Insufficient accuracy in pronunciation; many grammatically errors \\
\hline \multirow[t]{5}{*}{2.} & Grammar & 5 & a. Students make a few noticeable errors of grammar word order. \\
\hline & & 4 & b. Students occasionally make grammatical or word errors \\
\hline & & 3 & c. Students make frequent errors of grammar and word order \\
\hline & & 2 & d. Students have grammar and word errors make comprehension difficult. \\
\hline & & 1 & e. Students have errors in grammar and word order so severe as to make speech \\
\hline \multirow[t]{5}{*}{3.} & Vocabulary & 5 & a. Students' use of vocabulary and idioms is virtually that of native speaker. \\
\hline & & 4 & b. Sometimes, students use inappropriate terms or must rephrase ideas \\
\hline & & 3 & c. Students frequently are wrong words conversation somewhat limited \\
\hline & & 2 & d. Students misuse of word and very limited vocabulary \\
\hline & & 1 & e. Students have limitation vocabulary so extreme as to make conversation \\
\hline \multirow[t]{5}{*}{4.} & Comprehension & 5 & a. Students have speech as fluent and effortless as that native speaker. \\
\hline & & 4 & b. Students have speed of speech seems to be affected by language problems. \\
\hline & & 3 & c. Students have speed and fluently rather strongly. \\
\hline & & 2 & d. Students usually hesitant often force in to silence by language limitation. \\
\hline & & 1 & e. Students have speech is as halting and fragmentary as to make conversation \\
\hline \multirow[t]{5}{*}{5.} & Fluency & 5 & a. Students appear to understand everything without difficult. \\
\hline & & 4 & b. Students understand nearly everything at normal speed \\
\hline & & 3 & c. Students understand most what is said at slower than normal speed \\
\hline & & 2 & d. Students have great difficulty following what is said \\
\hline & & 1 & e. Students cannot say to understand even simple conversational English. \\
\hline
\end{tabular}

\section{RESULTS AND ANALYSIS}

\subsection{Observation}

This study is a Classroom Action Research in the Class X Automation and Office Management at Imanuel YPK Vocational high School, Sorong City. The researcher has carried out the previous observation process on the research subject. These observations relate to teaching techniques that the teacher uses and how the subject of the study receives the lesson. This is needed to recognize the environment in which the researcher must apply the technique. In accordance with the results of these observations, the researcher took the conclusion that the teacher had tried to apply active learning using songs and games. However, the technique researchers feel is not enough to encourage students to actively use English. Based on the results of these observations also help researchers prepare a research plan that will be delivered in the cycle. 


\subsection{Cycle 1}

In advance of starting the cycle, the researcher conducted a simple speaking pre test. Based on the pre test was known that the ability of the students were lack. The researcher prepared to set up a lesson plan to start the first cycle. This 1st cycle conducted in four meetings in each different class. This activity was attended by 75 students in 3 different classes of the Class X Automation and Office Management, meanwhile that there are 25 students in each class. The technique used is of course a chain story technique. In the first meeting, the researchers first divided the class into 5 small groups of 5 students in it. The division of this group is also done well, in which in one group there must be 2 students who the researcher considers to be the leader because of his English language abilities are more than others. This researcher adjusts to the ability of these students in the pre test. In the first meeting, the researcher was shared each group pieces of paper that contain words that if compiled will become a story. Each group is allowed to use a dictionary. Each group is given 30 minutes to compile the story. After that, each group reads the stories they have compiled. At first the students have not been able to arrange well and correctly, especially in the use of articles and to be. The researcher gave some advices especially the article and to be.

At the second meeting, the researcher brings a piece of picture to help students construct a story. The researcher asked the students in each group to one by one describe the picture then sequentially and continued by the other member at the same group. Students can arrange images correctly, but the words spoken are inappropriate according to English grammar, word selection also still does not vary. Based on the reflection, the researcher thought that she should give an energizer to help the students. The researcher conducted a new lesson plan to help the students conduct sentences in chain. At the third meeting, the researcher gave pieces of pictures and pieces of stories that must be matched and arranged. Each group is given time to arrange it. After that, each group reads the sentence that has been arranged according to the picture in front of the class, each student gets 1 picture and explains 1 picture, they can describe more than what they saw in the pieces of stories. Pictures in each group are different, so that the sentence used is also not the same. Students have done well but pronunciation of sentences is not exactly in accordance with the English pronunciation. After the third meeting, the researcher invited all students to read the story together according to the correct pronunciation. At the fourth meeting, the researcher gave a topic and the students were asked to give their opinion about it in their own group. Each group should give at least fifty words. The results of the value distribution of the Speaking test results can be seen in the following Table 2 .

Table 2. Recapitulation results of cycle I

\begin{tabular}{lllcc}
\hline No. & Category & Range Value & Frequency & Percentage (\%) \\
\hline 1. & Very Good & $85-100$ & 13 & 17 \\
2. & Well & $70-84$ & 19 & 25 \\
3. & Enough & $55-69$ & 23 & 31 \\
4. & Less & $0-54$ & 20 & 27 \\
& & Total & 75 & $100 \%$ \\
\hline
\end{tabular}

Based on the results of the first cycle, The researchers found that only $17 \%$ or 13 students scored very well, $25 \%$ or 19 students got good grades, $31 \%$ or 23 students got enough grades and $27 \%$ or 20 students got less marks. The dominance of values in cycle 1 is $31 \%$ with sufficient value and $27 \%$ with less value. The total percentage for very good and good is $42 \%$. Researchers still consider that the value achieved by students was not maximal. Thus the researcher decided to do the second cycle. The percentage of cycle is shown in Figure 2.

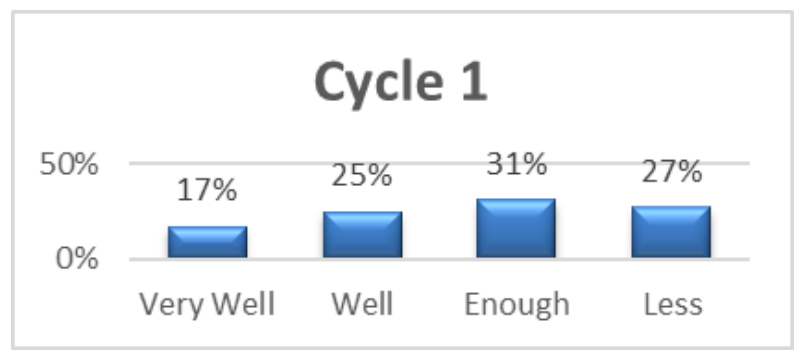

Figure 2. The percentage of cycle 1 


\subsection{Cycle 2}

Cycle 2 is applied to the same class with four times meeting. The researcher has prepared lesson plans that according to the results of the first cycle. The researcher thought that the students could arrange the sentence but it was not a perfect sentences according to its structure and they have not pronounced it correctly though. At the first meeting, researcher invited students to watch an English video with Indonesian subtitles. Then in groups, the students retell the story one by one in front of the class using English. In this first meeting, students began to be able to construct a sentence well, because the choice of words they had became far more when watching videos. The researcher trained the students to chain the story through subtitle video in the next second meeting. At the third and fourth meetings, researchers gave videos without subtitles to students but still with the same genre, fairytale cartoons. Students can well retell the story in front of the class in a chain. The students can retell the story because they remember the plot of the story. The teacher gave them time to prepare the sentences. After cycle 2, the researcher carried out a post test to see progress after applying the technique. A topic was given to the students then they should retell the story in chain. The results of cycle 2 are in the following Table 3.

Table 3. Recapitulation results of cycle II

\begin{tabular}{|c|c|c|c|c|}
\hline No. & Category & Range Value & Frequency & Percentage (\%) \\
\hline 1. & Very Good & $85-100$ & 35 & 47 \\
\hline 2. & Well & $70-84$ & 25 & 33 \\
\hline 3. & Enough & $55-69$ & 9 & 12 \\
\hline \multirow[t]{2}{*}{4.} & Less & $0-54$ & 6 & 8 \\
\hline & & Total & 75 & $100 \%$ \\
\hline
\end{tabular}

Based on the results of the first cycle, the researcher found that there were $47 \%$ or 35 students who scored very well, $33 \%$ or 25 students got good grades, $12 \%$ or 9 students got enough grades and $8 \%$ or 6 students got less grades. The dominance of values in cycle 2 is $47 \%$ with very good grades and $33 \%$ with good grades. The total score is very good and good in cycle 2 which is $80 \%$. The percentage of cycle 2 is shown in Figure 3.

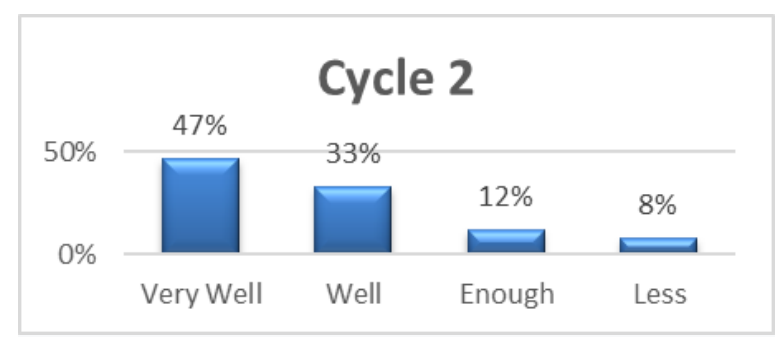

Figure 3. The percentage of cycle 2

\subsection{The Effectiveness of Research}

There is a very significant change towards the positive, when compared to the value of very good and good in cycle 1 which is $42 \%$ while in cycle 2 is $80 \%$, so there is an increase of $38 \%$. The comparison between cycle 1 and 2 is shown in Figure 4

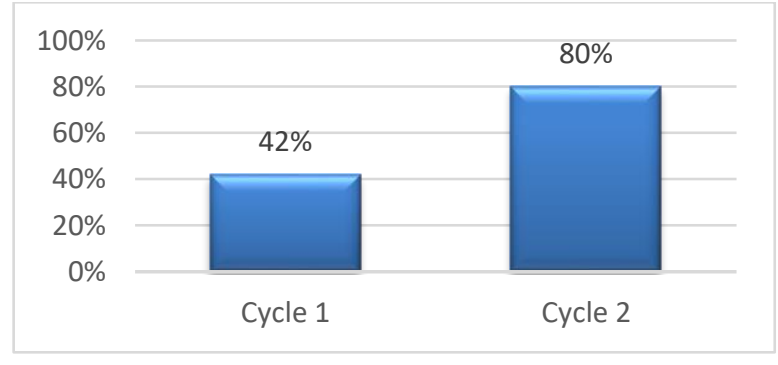

Figure 4. The comparison between cycle 1 and 2 


\subsection{Interview}

In this study, researchers also used interview to students to see students' perceptions of the implementation of learning with chain story techniques. Based on the interview, the students were happy and giving the good responses about the treatment and the progress they have done.

\section{CONCLUSION}

The purpose of this paper has been to tell the readers about the implementation of chain story technique in Imanuel YPK Vocational High School, Sorong City. Results of the study showed that: (1) Based on the observation, the students are changed to be more brave and confident to speak English; (2) Based on the test, there is a very significant change towards the positive, when compared to the value of very good and good in cycle 1 which is $42 \%$ while in cycle 2 is $80 \%$, so there is an increase of $38 \%$; (3)Based on the interview, the students were happy and giving the good responses about the treatment and the progress they have done.This chain story technique was running well and match to the need of those students in Imanuel YPK Vocational High School, Sorong City.

\section{ACKNOWLEDGEMENTS}

The authors thank to the Ministry of Research, Technology and Higher Education of the Republic of Indonesia, due to the funding of PDP 2018 for this work.

\section{REFERENCES}

[1] Waode Hamsia, "Developing Students' Speaking Ability Through Story Completion," Journal of English Language Teaching, vol. 5, no. 1, pp. 57-64, e-ISSN: 2548-5865, 2018. [Online]. Available: http://ojs.ikipmataram.ac.id/index.php/joelt,

[2] Pandey, M., and Pandey, P, "Better English for Better Employment Opportunities," International Journal of Multidisciplinary Approach and Studies, vol. 4, no. 1, pp. 93-100, 2014. [Online]. Available: http://ijmas.com/upcomingissue/10.04.2014.pdf,

[3] Ervina C. M. Simatupang, Hendar, Ida Zuraida Supri, "The Impact of Using Oraiapp.com on Improving Students' Speaking Skill for Non Native Speaker," Universal Journal of Educational Research, vol. 7, no. 4A, pp. 22-26, 2019.

[4] Penggabean, H, "Problematic Approach to English Learning and Teaching: A case in Indonesia English Language Teaching," English Language Teaching, vol. 8, no. 3, Canada: Canadian Center Of Science and Education,. pp. 35-45, 2015.

[5] Yuda Rahayu Erma Astutie, "Improving of English Speaking Ability Students Class VII of 1 Blitar City Junior High School Through Games Calendar (in Bahasa)," Jurnal Pendidikan: Riset \& Konseptual, vol. 2, no. 1, pp. 45-56, 2018. [Online]. Available: http://journal.unublitar.ac.id/pendidikan/index.php/Riset_Konseptual

[6] Tuan, N. H. and Mai, T. N, "Factors Affecting Students' Speaking Performance at Le Thanh Hien High School," Asian Journal of Educational Research, vol. 3, no. 2, pp. 1-23, 2015.

[7] Honang Adi Riyanto, "Improving Speaking Skill through Small Group Discussion," A Graduating Paper ERepository IAIN Salatiga., p. 18, 2015. [Online]. Available: http://www.erepository.perpus.iainsalatiga.ac.id/95/1/Honang\%20Adi\%20Riyanto\%20_11311114.pdf

[8] Riyaz, H. and Mullick, A.P, "Problems in learning English Speaking Skill: A Study of Higher Secondary Students in Srinagar, India," International Journal of Interdisciplinary and Multidisciplinary Studies (IJIMS), vol. 3, no. 2, pp. 59-69, 2016

[9] Mahripah, S, "Exploring Factors Affecting EFL Learners' Speaking Performance: from Theories into Practices," Proceedings of the 3rd UAD TEFL International Conference 2014 "Materials Development in Asia and Beyond: Directions, Issues, and Challenges." English Education Department, Universitas Ahmad Dahlan, Yogyakarta, Indonesia, 2014

[10] Al-Jarrah, J. M., Waari, O. T., Talafhah, R. H., and Al-Jarrah, T. M, "Improving English Grammar Achievement through Educational Games among Eleventh Grade Students in East Jerusalem," International Journal of Academic Research in Progressive Education and Development, vol. 8, no. 1, pp. 75-86, 2019.

[11] Lai-Mei Leong \& Seyedeh Masoumeh Ahmadi, "An Analysis of Factors Influencing Learners' English Speaking Skill," International Journal of Research in English Education, vol. 2, no. 1, pp. 34-41, 2017. http://ijreeonline.com/article-1-38-en.pdf

[12] Siska Apriyani, "Improving Students' Speaking Ability Using Chain Story Technique in Recount Text For Grade VIII of SMP N 1 Wates In Academic Year 2016/2017," English Language Teaching Journal, vol5, no. 9, pp. 1-5, 2016.

[13] Ahmadi, M. R, "The Impact of Motivation on Reading Comprehension," International Journal of Research in English Education, vol. 2, no. 1. pp 1-7, 2017. [Online]. Available: http://www.ijreeonline.com, March 20, 2017 
[14] Rokhayani, Atik and Agung Dwi Nur Cahyo, " Improving Student Speaking Skills Through English technique(in bahasa)," Refleksi Edukatika : Jurnal Ilmiah Kependidikan, vol 5, no. 1, pp. 1-12, 2015. [Online]. Available: https://jurnal.umk.ac.id/index.php/RE/article/view/439/470

[15] Fatah Huda, "An Investigation Of English Teaching Strategies In Enhancing Students' Vocabulary Implemented By A Pre-Service English Teacher," Journal of English and Education, vol. 4, no. 2, pp. 35-43, 2016. [Online]. Available: https://media.neliti.com/media/publications/191992-EN-an-investigation-of-english-teaching-str.pdf.

[16] Nanquil, Luisito, "Making a Difference through Effective Instructional Strategies," JET (Journal of English Teaching), vol. 5, no. 2, ISSN 2622-4224, pp. 135-143, 2019.

[17] Hermi Zaswita, "Conversation Circle Technique of Community Language Learning (CLL) for Better Speaking Ability," Curricula: Journal Of Teaching And Learning, vol. 4, no. 1, pp. 1-7, 2019. [Online]. Available: http://ejournal.kopertis10.or.id/index.php/curricula/article/view/3573/pdf21

[18] Leffi Noviyenty, "Strategies in Learning and Techniques in Teaching English Speaking," ENGLISH FRANCA : Academic Journal of English Language and Education, vol. 2, no. 1, pp. 35-48, 2018. [Online]. Available: http://journal.staincurup.ac.id/index.php/english/article/view/454/pdf

[19] Jeyasala, V.R, "A prelude to practice: Interactive activities for effective communication in English, Alternative pedagogies in the English language \& communication classroom," 4th CELC Symposium Singapore: Centre for English Language Communication National University of Singapore, pp.164-170, 2014.

[20] Vanessa Toro, Gina Camacho-Minuche, Eliana Pinza-Tapia \& Fabian Paredes, "The Use of the Communicative Language Teaching Approach to Improve Students' Oral Skills," Journal of English Language Teaching. Published by Canadian Center of Science and Education. vol. 12, no. 1, pp. 110-118, 2019.

[21] Siska Apriyani, "Improving Students' Speaking Ability Using Chain Story Technique in Recount Text For Grade VIII of SMP N 1 Wates In Academic Year 2016/2017," English Language Teaching Journal, vol. 5, no. 9, pp 1-5, 2016.

[22] Iponiasih, "The Influence of Using Chain Story Activity on Procedural Text towards Students' Speaking Skill," JEES: Journal of English Education Studies, vol. 1, no. 1, pp. 1-7, 2018.

[23] Fitriani, Lusi \& Muslih Hambali, "Teaching Speaking Through Chain Storytelling to the Tenth Grade Students of SMA Srijaya Negara Palembang," The Journal of English Literacy Education vol. 6, 2019. [Online]. Available: https://ejournal.unsri.ac.id/index.php/jenglish/article/view/9993.

[24] Gamal, et al, "The Effect of Chain Story in Writing Narrative Text on The Second Year Students of SMAN 5 Pekanbaru," Jurnal Online Mahasiswa Fakultas Keguruan dan Ilmu Pendidikan Universitas Riau, vol. 5, no. 1, pp. 1-9, 2018.

[25] Narendra, "The Implementation of Chain Story Game to Teach Speaking in Recount Text for Eighth Graders of SMPN 39 Surabaya," Retain, vol. 4, no. 1, pp. 1-9, 2016.

[26] Lestari, N, "Improving the Speaking Skill by Vlog (video blog) as Learning Media: The EFL Students Perspective," International Journal of Academic Research in Business and Social Sciences, vol. 9, no. 1, pp. 915-925, 2019.

[27] Kusamah, Wijaya and Dwitagama, Dedi., Knowing classroom action research (in Bahasa), Jakarta: PT. Idenks, 2009.

\section{BIOGRAPHIES OF AUTHORS}


Lulu Jola Uktolseja is a lecturer of English Department, Victory University of Sorong. She finished her magister education in Cendrawasih University of Jayapura. She is also the active volunteer in SD YPK Klasaman 2 Sorong who has been teaching English for 6 years. She has done several researcher in the term of English Education and linguistic.

Sherly Gaspersz is the Dean of Faculty Teacher Trainning and Education Science, Victory University of Sorong. She is active in doing literature research. She is also active as the Sunday school teacher. 